\title{
Statistics of Productivity and Effectiveness of Experimental Support of the Educational System (For Scientists and Education Experts)
}

\author{
Aleksandra I. Galkina ${ }^{1}$ \\ Elena Yu. Bobkova² \\ Ekaterina A. Burnasheva1 \\ Igor A. Grishan ${ }^{1}$ \\ Maria V. Komarova ${ }^{1}$ \\ ${ }^{1}$ Federal Public Budgetary Scientific Institution "Institute of Management of Formation of the Russian Academy of Education" \\ Joint Fund of the Electronic Resources "Science and Education», 119121, Moscow, Russia \\ ${ }^{2}$ Samara Cossack Institute of the Food Industry and Business (Branch) Moscow State University of Technologies and \\ Management Named after K. G. Razumovsky (The First Cossack University) 443031, Samara, Russia
}

Doi:10.5901/mjss.2015.v6n5s3p62

\section{Abstract}

The present article focuses on the issues of productivity and effectiveness of research providing educational system. This work describes research activity as an activity of the authors- individuals and groups of the authors, and also an activity of scientific and educational institutions which are carrying out their activity within the education system in the field of development, registration, approbation and implementation of teaching and education techniques and technologies, new mechanisms of management in the education system, control of the quality of education and also in other directions provided by the programs of education development and other normative legal acts defining priorities of the state education policy of the Russian Federation. The article has considered the dynamics of a branch registration of the results of intellectual activity (RIA) in the field of education in recent years. It has also given the statistics of scientific providing education system on materials of a database and information collections of the Joint fund of Electronic Resources "Science and education" (JFERSaE). The examples of integrating collections of electronic resources developed by the JFERSaE experts have been considered. The systematized review of specifics of the technology of a branch registration of electronic resources is a distinctive feature of the work. Now an actual problem for many authors creating various objects of the intellectual property for the education system is a legal protection of their rights. The legislator for computer programs says, many types of works existing only in the electronic form do not provide for a special registration, databases, etc. A the same time, the authors- workers of educational institutions in the course of implementation of the labor functions often face a need of the authors' rights confirmation for their electronic works included in electronic educational systems and forming in turn information and education space of a country.

Keywords: results of intellectual activity, electronic educational resources, registration, scientific providing education system, scientific publication.

\section{Introduction}

Now one of the priority tasks of almost any civilized state is the effective policy in the area on development of the scientific and technical sphere that considerably enhances the level of works competitiveness at the world market and will positively affect the export dynamics of the science intensive output. From the beginning of the XXI century in almost all spheres there is a steady tendency to the growth in number of the results of the intellectual activity (within the labor functions performance) established by employees of various organizations and institutions. In the second decade of the XXI century it is separately possible to emphasize the educational sphere where an innovative activity becomes one of the criteria of the organization competitiveness (Solomonenko, 2014). Many researchers note that today the enough intellectual activity results have an official character, i.e. they are created in connection with performance by the worker of his labor duties or a concrete task of an employer (Dobrynin, 2014) that is explained by the following fact: commercialization of objects of the intellectual property demands a great number of financial, technological, technical means which can be concentrated in large economic subjects. Now the Joint Fund of Electronic Resources "Science and 
education"(further in the text of work - (JFERSaE) is almost the only organization specializing on a branch registration of electronic resources of science and education of different types in the territory of the Russian Federation.

Within the article an analysis in the issues of the level of productivity and effectiveness of research providing educational system that is formed due to the works which have already underwent all necessary procedures of a registration in JFERSaE is conducted. By research activity in this case is understood an activity of the authors- individuals and groups of the authors, and also an activity of scientific and educational institutions which are carrying out their activity within the education system in the field of development, registration, approbation and implementation of teaching and education techniques and technologies, new mechanisms of management in the education system, control of the quality of education and also in other directions provided by the programs of education development and other normative legal acts defining priorities of the state education policy of the Russian Federation. At the macrolevel a test of the new content of education and the educational systems by experience, new pedagogical technologies, textbooks, educational and methodical, methodical, educational and laboratory sets; - approbation of new mechanisms directed on modernization of the education management including economics of education; creation and development of new structures in the education system, network interaction of educational organizations and educational systems; development and a test of systems of an assessment of the quality of education by experience, new forms and methods of the education management; development and approbation of new means of ensuring of public support of education development programs; approbation and implementation of new forms, methods and tutorials; development and approbation of new directions of preparation (specialities), specializations, and also new educational services; research, innovative activity on urgent problems of education directed on improvement of educational and methodical, organizational, legal, financial and economic, personnel, material support of the education system are the main objectives of development of research providing educational system. The objectives set at the microlevel often coincide with functionality of the profile organizations which are carrying out a direct formation of research providing educational system.

In general, in the course of functioning of the domestic system of a registration of the results of intellectual activity at the federal level the Federal Public Autonomous Scientific Institution "The center of Information Technologies and Systems of Federal Executive Authorities" of the Ministry of Education and Science of the Russian Federation (to FPASI CITaS - the former VNTIZ - the All-Russian Scientific and Technical Information Center); - the Federal Service for Intellectual Property (ROSPATENT) (the departmental submission to the Ministry of Economic Development of the Russian Federation) take part.

FPASI CITaS is carried out a formation of the fund of unpublished sources of the scientific and technical information (STI) as a component of the national library and information fund of the Russian Federation.

The work of the Uniform information system of the accounting of the results of research, developmental and technological works is supported by the branch funds of a registration of the results of intellectual activity (RIA) existing in various areas of economics of the country: health care, transport, education, defense, etc. The branch funds are focused on specifics of areas of economics of the country which they serve.

In the education system the Joint Fund of Electronic Resources "Science and education" (JFERSaE) which is the scientific partner to the FPASI CITaS assumes the functions of an assessment of novelty and priority of the intellectual activity results. Within the article the research of productivity and effectiveness of research providing educational system (for scientists and education experts) on JFERSaE materials for the last period is conducted.

The research aim is to study tendencies of development of research providing educational system at the beginning of the second decade of the XXI century.

\section{Literature Review}

Certain researchers as well as the authors' groups in the sphere of science and education were engaged in study of the dynamics of a development vector of electronic works. So, for example, reviews of the results of a registration in Rospatent (2013) are periodically published in the magazine «Birzha Intellektualnoi Sobstvennosti», a number of the authors conduct a comparative analysis of the author's activity on the materials of Russia and Turkey (Fyodorov V. K. and Akylla Kh. (2015). A number of authors investigate development of a registration of the intellectual property in separate branches (Trifonov M.V. and Kuznetsova O. A., 2014; Bobkova E.Yu., 2015). Regular analytical reviews of a general character (Galkina A.I., Soshnikova E.A., Bobkova E.Yu., Grishan I.A. 2014; Galkina A.I., Bobkova E.Yu., Burnasheva E.A., Grishan I.A., Komarova M. V., 2014) and reviews devoted to the certain types and forms of electronic resources, and also their roles in the organizations' activity (Galkina A.I., 2014;) as well as scientific works devoted to the technology of a registration of electronic resources included in JFERSaE base, also JFERSaE employees publish (Galkin 
A.I., 2012). Problems and prospects of the legal protection of electronic resources created as office works both in organizations of a various form of ownership (Dobrynin by B.O, 2014) and in educational institutions (Solomonenko L.A., 2014) attract in recent years a great interest of Russian researchers that emphasizes the relevance of the research which results are presented in this work.

\section{Methods and Materials}

Methods of a historical, systematic, logical analysis, scientific cognition (a comparison, an analysis, a synthesis, an analogy, a generalization, an induction, and a deduction), a logical method and classification are the methodological basis of the research. The methodology of mathematical statistics, mathematical models and methods of the analysis with the use of modern computer technologies was used for the statistical analysis conduction.

\section{Results and Discussions}

The Joint Fund of Electronic Resources "Science and education" (further JFERSaE), established on 30 November 2009 by the Order of the director of the FSSI ISAPI RAE, is guided by doing its activity by the federal legislation, the Charter, normative acts of the FSSI ISAPI RAE and the Status. Now JFERSaE is a structural department of the Federal Public Budgetary Scientific Institution "Institute of Education Management of the Russian Academy of Education" and has an extensive network of regional and specialized branches all over the country. Almost all branches successfully operate on the basis of educational institutions (higher education institutions, colleges, schools, junior colleges, etc.).

JFERSaE is the historical assignee of a number of organizations conducting the funds of algorithms and programs in the educational system see Figure 1.

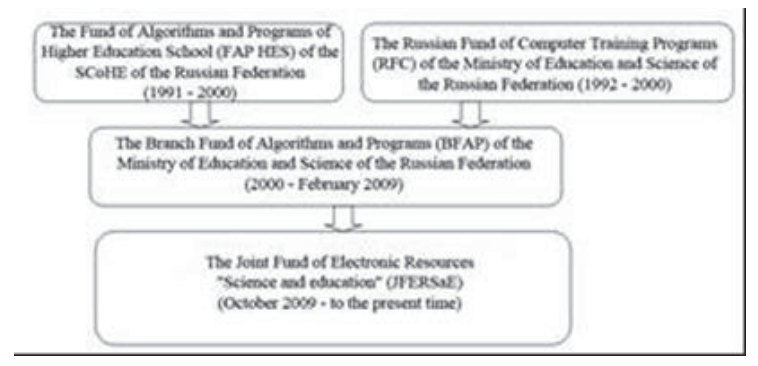

Figure 1 - Chronology of development of the fund of electronic resources

In 2000 there was an integration of the Fund of Algorithms and Programs of Higher Education School (FAP HES) and the Russian Fund of Computer Training Programs (RFC) in the Branch Fund of Algorithms and Programs (BFAP). This key circumstance, and also an emergence of the OFAP site in 2004 became the strongest incentive of promoting of a procedure of the results of intellectual activity of science and education registration that has led to the stream increase of works in a digital code (Figure 2)

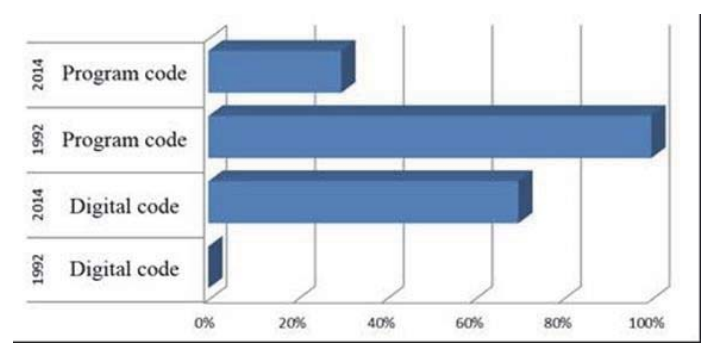

Figure 2 - Ratio of the results of the intellectual activity in a program code and digital code, units of registered resources (in comparison of data of 1992 and 2014) 
In 2013 the fund was finally established as the departmental and passed to a registration of the results of the intellectual activity into the fields of education and pedagogical science (Figure 3). Figure 3 shows the dynamics of change of a ratio of electronic resources in education and other branches of economics within a year.

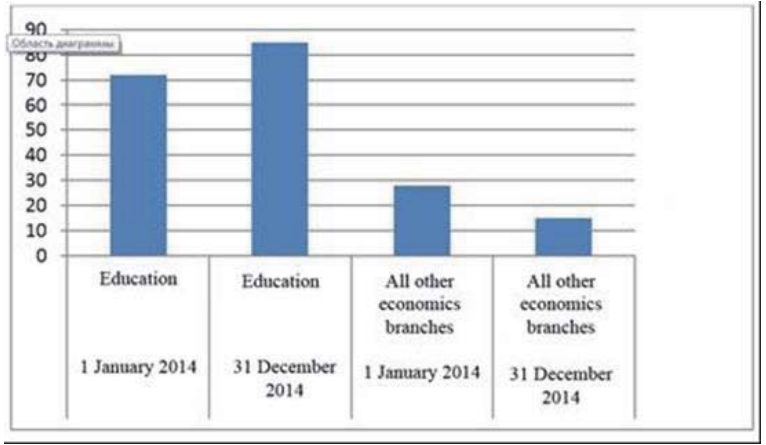

Figure 3 - The percentage ratio of electronic resources of science and education and other economics branches relating to January and December 2014)

Now the United Fund of electronic Resources "Science and education" is intended for accumulations of information about electronic resources of science and education having "unpublished documents" appearance; standardization and unification of semistructured information about electronic resources; estimates of electronic resources of science and education on compliance to requirements of novelty and priority; cataloguing of electronic resources of scientific and educational appointment; providing the available, full and transparent notification of scientific and pedagogical community of the country about the last achievements in the field of science and education.

The main objectives of the Joint Fund of Electronic Resources "Science and education" are carrying out an evidence-based state policy in the field of formation of a common information space of science and education about the results of the intellectual activity (RIA) on the basis of the wide use of information and communication technologies; providing developers and consumers of electronic resources of science and education with available, full, reliable and operational information concerning electronic providing science and education; providing conditions for elimination of unjustified duplication of electronic resources of science and education and, thereby, elimination of irrational budgetary financing of fundamental and applied researches and the results of design activity in science and education.

Functions of the Joint Fund of Electronic Resources «Science and education» are consultation of the authors and organizations of electronic resources developers of science and education for a registration of electronic resources of science and education (including the issues on registrations of a set of documents, classifications and rubrications on SRSTI and UDC, identifications on the USPD code, a branch classification and rubrication); consultation on precepts of law of the author's right for the intellectual property; an assessment of novelty and priority of electronic resources of science and education; registration (account) of electronic resources of science and education; cataloguing of electronic resources of science and education; assistance to the authors and organizations-developers in a registration of electronic resources of science and education in the National Information Fund of Unpublished Documents (FPSI "CITaS"); a placement of information about electronic resources of science and education, including a contact information of the authors and organization-developers on a portal of the Joint Fund of Electronic Resources "Science and education" and also in electronic editions; a placement of information about innovative electronic resources in the field of science and education on a portal of the Joint Fund of Electronic Resources "Science and education".

The fund is a scientific partner of institutions which are engaged in a registration of the intellectual property and also interacts with them for the purpose of observance and protection of the authors' rights of the results of the intellectual activity. The information about ROSPATENT, FPSI "CITAS", STC "INFORMREGISTR" is often given on pages of a portal, in the news line, and that also helps the authors to be guided with the directions of a legal protection of the author's right for his works.

Over the years the legal education which has accepted a mass character; an emergence of the numerous legal sites; legal telecasts; and also promotional activity of the fund on the authors' rights questions, promoted the legal education of scientific and pedagogical community of the country. 
Besides the technology of a registration in JFERSaE which is followed by the operational and mass notification of scientific and pedagogical community of the country about the results of a registration on a portal of the fund, is the recognized practical mechanism of a preventive protection of the author's right of the intellectual property.

At all times an activity of the fund was aimed at providing recognition of the results of research activity of the authors and organizations-developers from scientific and pedagogical community. Figure 4 presents the structure of users of the fund.

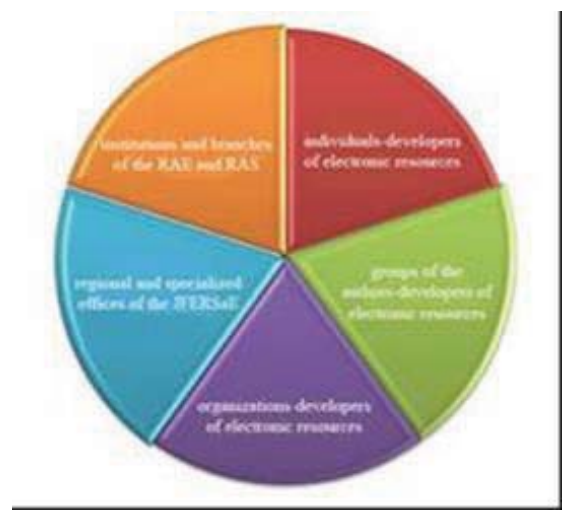

Figure 4 - The main users JFERSaE

The monitoring which is regularly carried out by JFERSaE employees says that for June 2015 a number of JFERSaE users are more than 40000 people (the authors-individuals and groups of the authors - developers of electronic resources), and also about 700 organizations-developers of electronic resources.

JFERSaE is the two-level structure including besides the head office, JFERSaE itself, and 30 regional and specialized offices covering by their activity a great part of Russia. JFERSaE offices are experimental platforms on scientific work in the field of development and deployment of research providing educational system (for scientists and education experts). The monitoring of number of the registered development on time (Fig. 5) shows both an increasing and a weakening interest of the scientific and pedagogical public to a voluntary registration of the results of the intellectual activity in JFERSaE for their assessment of novelty and priority.

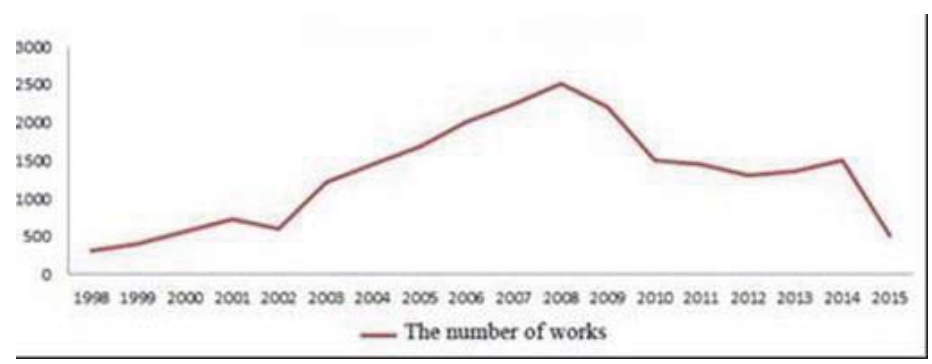

Figure 5 - The dynamics of number of the registered works about from the creation moment to the present time

At all stages of formation, making up and development of the branch fund of the education system its users - authors in the conditions of the legal insufficiency caused by a lag of lawmaking from realities of promptly developing world were interested in the issues on the author's right for the registered work, the issues on the right possession, the issues on the interaction of the fund and the lead agencies dealing with the issues of a registration of the results of the intellectual activity and their protection. Registration in branch fund became the instrument of practical, preventive protection of copyright of the registered development.

The analysis of a JFERSaE database on headings of the State Rubricator of Scientific and Technical Information 
(SRSTI) convincingly shows an advantage of scientific and research works (fundamental and applied) in the fieldsof education and pedagogics. Today the fund fulfilled more than 250 various, standard issues on which the answers published on a portal are given. These questions-answers have in total 38058 viewings that is a good indicator for a highly specialized portal.

By the results of the analysis of functionality of the results of the intellectual activity registered in JFERSaE, systematization of classification signs of RIA that allowed formulating a further classification of the results of the intellectual activity registered in JFERSaE, see Figure 6 was carried out.

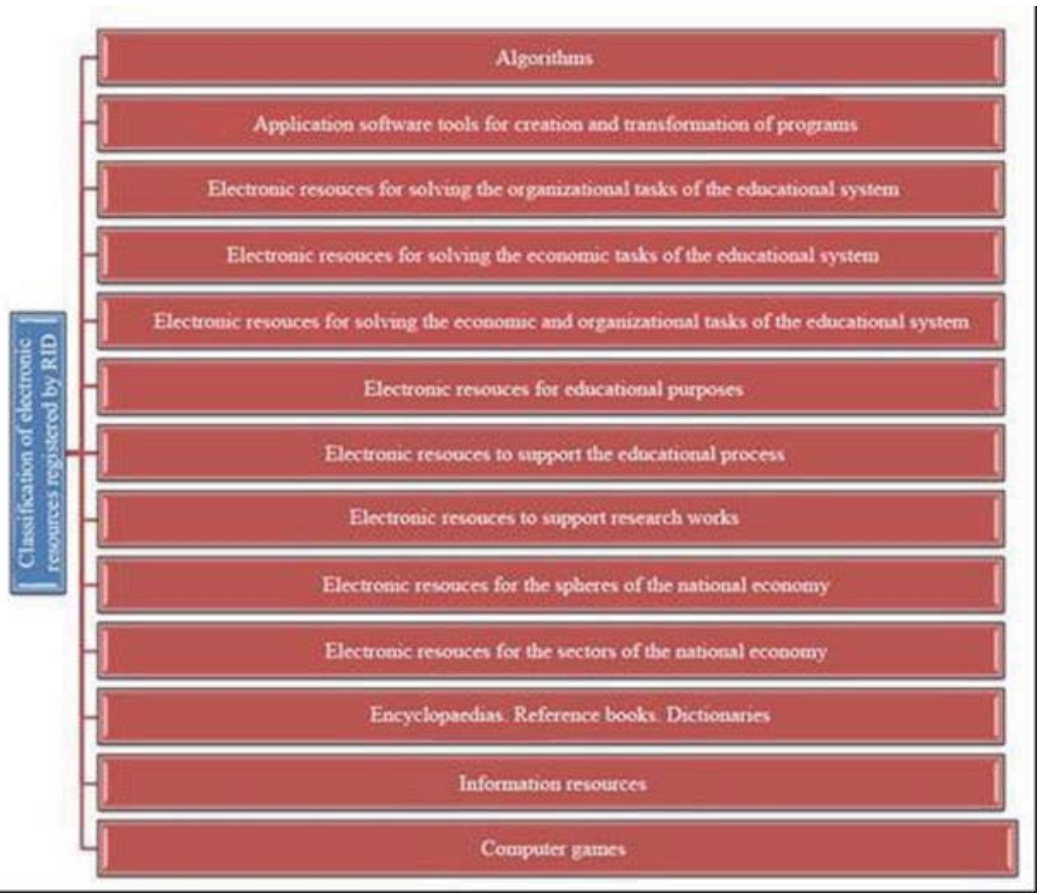

Figure 6 - Classification of electronic resources registered in JFERSaE in recent years

Evolution of the fund led to a registration of electronic resources and first of all electronic educational resources in a digital code, having the primary majority, in the general set of the registered results of the intellectual activity. The quantitative analysis of the registered results of the intellectual activities according to functionality allows making a conclusion about the prevalence of electronic educational resources (EER) $-47.8 \%$ of RID total. Electronic educational resources in a digital code have more than 600 versions with a complete list of which it is possible to get acquainted on JFERSaE portal. The quantity of electronic educational resources kinds in a digital code increases from year to year reflecting an improvement of the forms of components of the scientific and educational environment of educational institutions, depending on reforming and modernization of the education system.

Electronic educational resources to which electronic resources for the solution of organizational problems of the education system; electronic resources for the solution of economic problems of the education system; electronic resources for the solution of organizational and economic problems of the education system; electronic resources of the educational appointment; electronic resources of support of the educational process; encyclopedias, reference books, dictionaries; information resources; developing computer games in their entirety compound components of the information and education environment of educational institutions refer.

Now various researches show that more than $83 \%$ of the full volume of the intellectual property in the education system works in a digital code present. The digitized educational and methodical grants, elective author's courses, certification pedagogical materials, etc. having a high intellectual value were highly appreciated by the scientific and pedagogical community, especially, abroad. Now the existence and quality of the information and education environment 
of the educational process organization of the educational institution is a defining point in a preparation of the highly qualified labor and scientific personnel demanded by economics and economy of the country that follows the State program on training of the top skills (2012-2014 years).

The analysis of the electronic educational resources (EER) distribution (Figure 7) registered in JFERSaE by years convincingly shows that the splash of the quantity growth of the developed and registered electronic educational resources coincides on time with the beginning of the system of higher education reforming - with a year 2008.

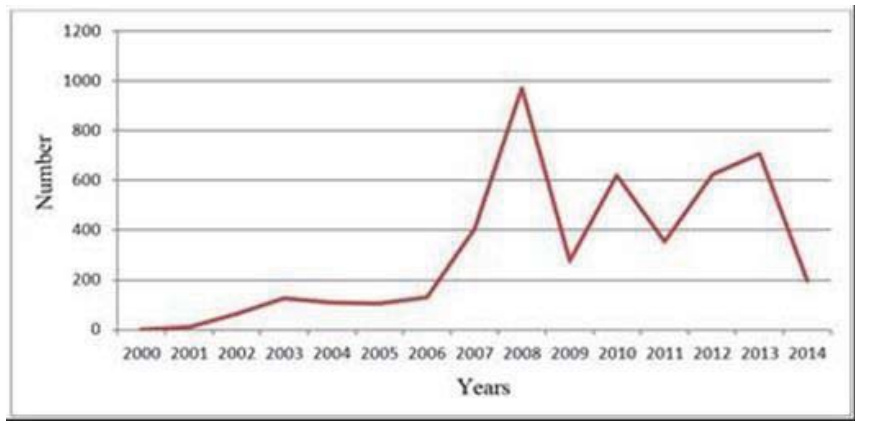

Figure 7 - Distribution registered in JFERSaE EOR by years

At a registration of the results of the intellectual activity in JFERSaE the developers note a kind of the registered the results of the intellectual activity. The version is classified according to a registration form of ICR registration (the Information Card of Results of Intellectual Activity) in the following way: a program module, a program, a software package, an application suite, a library of programs, a program system, a program complex, an information structure, and others.

On the basis of the carried-out analysis of the registered electronic resources of the educational appointment, it is possible to note that in recent years the "Others" version considerably is in the lead, occupying in 2014-2015 more than $70 \%$ of all registered EO of this type.

The "Others" version of the registered EOR contains more than 600 subspecies including the Automated Pedagogical Measuring Materials, the Album of Assembly Drawings, the Bank of Practical Tasks, the Video of a task, the Visual notebook, the Hypertext textbook, the Book of problems, Interactive laboratory work, the Case of distance learning, the Case-study, the Abstract of a lesson, the Lecture-concert, Materials of the international seminar, Methodical and didactical textbook, the Methodical note, the Multimedia manual, the Multimedia educational and methodical textbook, the Reference book for a teacher, the Training video course, the Textbook for a pupil, the Working program of the author's elective course, the Workbook, the Answer book, The Series of slide movies, Terminological training, the Educational video course, the Electronic alphabet, the Electronic herbarium, the Electronic educational and training practical work, etc. reflecting all variety of electronic educational resources - the results of the intellectual activity of the faculty of the education system regarding the improvement of methodology of training and education.

The quantity of subspecies of a "Others" version increases from year to year reflecting the improvement of the forms of components of the information and education environment of educational institutions depending on reforming and modernization of the education system. This situation is most clearly demonstrated by the improvement of a form of the registered textbooks (educational, educational and methodical, methodical, methodical and didactical, etc.) depending on the period of their development (table 1).

Table 1 - Kinds of textbooks on time of their development and registration:

\begin{tabular}{|l|l|}
\hline The form of a textbook & The development and registration period \\
textual & the early 2000s \\
hypertext & the mid-2000s \\
interactive & the late 2000s \\
electronic & the early 2010s \\
multimedia & from 2010 to the present time \\
\hline
\end{tabular}


If to analyze the quantitative and qualitative structure of electronic educational resources carried to the "Others" version, there is a primary prevalence of textbooks which make $73 \%$ of the total quantity of the registered EOR.

Informatization of education was an incitement to EOR development, creation of the information and education environment of the education system, creation of systems of open and remote education.

Thus, the practical result of basic and applied scientific researches in the fields of education and pedagogics is the development of various electronic educational resources meeting the pressing needs of the education system for effectiveness of the implementation of scientific and technical programs aimed at the advancing innovative development of economy and economics of the country.

Novelty of the registered electronic educational resources is shown by the following example.

In a JFERSaE database nearly 1500 electronic textbooks on informatics among which it is impossible to find two identical ones. All textbooks differ in the hardware-software characteristics, development tools, a focus on various education levels, a focus on various levels of higher school, a focus on different specialities and specialization of specialists training (respectively, the volume and intensity of the training material), a ratio of educational and methodical components, an existence or absence didactic components, an availability of control measuring materials, etc.

Retrospective analyses of the maintenance of a JFERSaE database give an evident picture of the development and modernization of education in Russia. In a database scientific providing education system since the end of the period of a computerization of education is accumulated (1985-1993 years) to the present time - the period of the State program "Information society" realization.

In this plan the JFERSaE experiment on development of the retrospective generalizing collections of higher education institutions and schools is interesting. On JFERSaE materials the following electronic editions were developed in recent years: Components of the information and education environment of the Armavir State Pedagogical Academy (on materials of the Joint Fund of Electronic Resources "Science and education" 2006-2013) / To FPBEI HPE APPA the 65th anniversary; the Components of the scientific and educational environment of Omsk State Technical University (on materials of the Joint Fund of Electronic Resources "Science and education" 2001-2013); the Components of the educational and scientific environment of Nizhny Tagil State Social and Pedagogical Academy (on materials of the Joint Fund of Electronic Resources "Science and education" (2001-2013) ; the Information and Education environment of the Public Budgetary Educational Institution Gymnasium №1526 (Moscow) / To the 20th anniversary of SEI a gymnasium № 1526 (Moscow) (2004-2014years).

Each electronic edition contained the retrospective review of electronic educational resources registered by these educational institutions in JFERSaE for many years; the catalogued collection of electronic resources in the form of the Russian and English versions of JFERSaE electronic edition "The navigator in the world of science and education"; collections of the full-text advertisement technical specifications registered by the EOR with the indication of direct references on JFERSaE portal and direct references on servers of educational institutions within information and education environments of educational institutions.

All electronic editions were registered in addition in accordance with the established procedure in STC INFORMREGISTR that allowed to present electronic editions to the federal libraries of the country which are a part of the National repository of domestic printing editions. Thereby the circle of experts, the scientific and pedagogical workers of the country acquainted with scientific and pedagogical activity of the above-named educational institutions has extended.

All information going to JFERSaE is in full and direct access to scientific and pedagogical community on Information portal of the Joint Fund of Electronic Resources "Science and education" available at www.ofernio.ru because the publication in open access significantly complicates a possibility of plagiarism and increases the quality of scientific researches.

Acquaintance and work with a database and collections JFERSaE does not demand special registration on a portal, however, use of materials JFERSaE is admissible at obligatory references to a portal.

Openness of the JFERSaE Information portal follows the Status on the Standard of openness introduced in the executive authorities. However, concerning the personal information provided by the authors-individuals and groups of the authors for the implementation of a registration procedure by the fund, the fund is guided by the Status on the JFERSaE privacy policy according to which the fund undertakes to keep, not to provide and not to open a personal information to the third persons.

Users of the fund addressing to the fund agree with the JFERSaE Privacy policy and agree with the publication of an abstract information about the registered by RID and a placement of the full-text descriptions of the registered electronic resources on a portal of the fund.

Openness, availability and informational content of the Information portal of the Joint Fund of Electronic Resources "Science and Education" were appreciated by the pedagogical community of the country and other countries of the world. 
Except the Russian part of the Internet a portal causes both the experts' of other countries and regions' of the world interest. According to the rating system "Live Statistics Globe" portal is visited by the experts in more than 30 countries of the world: Azerbaijan, Antigua and Barbettes, Argentina, Belarus, Belgium, Bosnia and Herzegovina, Botswana, Brazil, Great Britain, Venezuela, Germany, Israel, Spain, Italy, Kazakhstan, China, Macedonia, Mexico, Netherlands, Poland, Republic of Korea, Czech Republic, Saudi Arabia, United States of America, Tajikistan, Thailand, Turkey, Ukraine, Chile, Sweden.

The results of a registration in JFERSaE are made out by the list of scientific publications according to AUSS and models of a registration presented on a portal.

\section{Conclusion}

At the present stage the scientific community has developed criteria for identification of the priority directions in science, the main thing from which is an introduction of the results of scientific researches in practice. Productivity and effectiveness of scientific providing education system accumulated in JFERSaE is confirmed by the practice of its introduction and use in the real pedagogical process.

\section{References}

Solomonenko, L.A. (2014) Osobennosti pravovoi ohrany proizvedeny, sozdannyh v poryadke vypolneniya trudovyh obyazannostei v vysshem obrazovatelnom uchrezhdenii: Avtoref. diss. kand. jurid. nauk. M., 2014. Available at http://dis.rgiis.ru/files/dis/d40100 102/solomonenko-200314/solomonenko-200314-a.pdf

Dobrynin, V.O. (2014) Rossijskoe i zarubezhnoe pravo: regulirovanie voprosov v sfere sluzhebnogo izobretatelstva // Intellektualnaja sobstvennost. Promyshlennaya sobstvennost. № 6.

Statisticheskie dannye Rospatenta o gosudarstvennoi registratsii sredstv individualizatsii, programm dlya EVM, baz dannyh, topology integralnyh mikroshem, a takzhe dogovorov o peredache prav na obekty intellektualnoi sobstvennosti // Birzha intellektualnoi sobstvennosti. T. 12. № 5. pp. 63-68.

Fyodorov, V.K. and Akylly Kh. (2015) Sravnitelnyi analiz izobretatelskoi aktivnosti v innovatsionnyh protsessah v Rossii i Turtsii /l Ekonomika i upravlenie v mashinostroenii. № 2. pp. 35-38.

Trifonov, M.V. and Kuznecova O.A. (2014) Intellektual'naja sobstvennost' mjasnoj otrasli // Vse o mjase. № 4. pp. 4-6.

Bobkova, E.Ju. (2015) Predikativnaya model istochnikovoi bazy po problemam zashhity intellektualnoi sobstvennosti vo vtorom desyatiletii XXI veka (na materialah natsionalnoi bibliograficheskoi bazy dannyh nauchnogo tsitirovaniya «Rossijsky indeks nauchnogo tsitirovanija») // Politika, gosudarstvo i pravo. № 3. pp. 42-49.

Galkina, A.I., Soshnikova E.A., Bobkova E.Yu. and Grishan I.A. (2014) Statistika rezultativnosti i effektivnosti nauchnogo obespecheniya sistemy obrazovaniya // Informatizatsiya obrazovaniya i nauki. № 4 (24). pp. 177-190.

Galkina, A.I., Bobkova E.Yu., Burnasheva E.A., Grishan I.A. and Komarova M.V. (2015) O Rezultatah intellektualnoi dejatel'nosti (RID) na osnove shirokogo ispol'zovanija informacionnyh i kommunikacionnyh tehnology (na primere materialov OFJeRNIO za 2014 god) // Khroniki obedinennogo fonda elektronnyh resursov Nauka i obrazovanie. T. 1. № 1 (68). pp. 43.

Galkina, A.I. and Kadyrova E.A. (2014) Bibliometrichesky analiz elektronnyh obrazovatelnyh resursov dlya distantsionnogo obrazovaniya (po materialam OFJeRNIO) // Aktualnye problemy gumanitarnyh i estestvennyh nauk. № 12-3. pp. 146-153.

Galkina, A.I. (2014) Delovaya reputatsiya i imidzh rossijskih vuzov (po materialam Obedinennogo fonda elektronnyh resursov «Nauka i obrazovanie») /I Novye informatsionnye tehnologii v obrazovanii Materialy VII mezhdunarodnoi nauchno-prakticheskoi konferentsii. Rossijsky gosudarstvennyi professionalno-pedagogichesky universitet. Ekaterinburg. pp. 304-308.

Galkina, A.I. (2012) Teoriya i praktika elektronnoi registratsii rezultatov intellektualnoi deyatelnosti rabotnikov nauki i obrazovaniya /I Informatizatsiya obrazovaniya i nauki. № 13. pp. 132-145. 